\title{
Correction to: Incidence of thromboembolism in patients with COVID- 19: a systematic review and meta-analysis
}

\author{
Kochawan Boonyawat ${ }^{1 *}$, Pichika Chantrathammachart ${ }^{1}$, Pawin Numthavaj ${ }^{2}$, Nithita Nanthatanti ${ }^{3}$,
} Sithakom Phusanti ${ }^{3}$, Angsana Phuphuakrat ${ }^{1}$, Pimjai Niparuck ${ }^{1}$ and Pantep Angchaisuksiri ${ }^{1}$

\section{Correction to: Thromb J (2020) 18:34 \\ https://doi.org/10.1186/s12959-020-00248-5}

Following the publication of the original article [1], the authors identified an error in the name of one of the authors.

The incorrect name was: Pawin Numthavej

The correct name is: Pawin Numthavaj

The author group has been updated above and the original article [1] has been corrected.

\footnotetext{
Author details

'Department of Medicine, Faculty of Medicine Ramathibodi Hospital, Mahidol University, Bangkok, Thailand. ${ }^{2}$ Department of Clinical Epidemiology and Biostatistics, Faculty of Medicine Ramathibodi Hospital, Mahidol University, Bangkok, Thailand. ${ }^{3}$ Chakri Naruebodindra Medical Institute, Faculty of Medicine Ramathibodi Hospital, Mahidol University, Samut Prakan, Thailand.
}

Published online: 29 December 2020

\section{Reference}

1. Boonyawat $K$, Chantrathammachart $P$, Numthavaj $P$, et al. Incidence of thromboembolism in patients with COVID-19: a systematic review and meta-analysis. Thromb J. 2020;18:34. https://doi.org/10.1186/s12959-02000248-5.

The original article can be found online at https://doi.org/10.1186/s12959020-00248-5

* Correspondence: Kochawan.boo@mahidol.ac.th

'Department of Medicine, Faculty of Medicine Ramathibodi Hospital, Mahidol University, Bangkok, Thailand

Full list of author information is available at the end of the article

(C) The Author(s). 2020 Open Access This article is licensed under a Creative Commons Attribution 4.0 International License, which permits use, sharing, adaptation, distribution and reproduction in any medium or format, as long as you give appropriate credit to the original author(s) and the source, provide a link to the Creative Commons licence, and indicate if changes were made. The images or other third party material in this article are included in the article's Creative Commons. licence, unless indicated otherwise in a credit line to the material. If material is not included in the article's Creative Commons licence and your intended use is not permitted by statutory regulation or exceeds the permitted use, you will need to obtain permission directly from the copyright holder. To view a copy of this licence, visit http://creativecommons.org/licenses/by/4.0/. The Creative Commons Public Domain Dedication waiver (http://creativecommons.org/publicdomain/zero/1.0/) applies to the data made available in this article, unless otherwise stated in a credit line to the data. 